\title{
Thoracic epidural anesthesia attenuates hemorrhagic-induced splanchnic hypo-perfusion in post-resuscitation experimental hemorrhagic shock
}

\author{
Amir S Madjid
}

\begin{abstract}
Abstrak
Tujuan penelitian ini adalah untuk menilai pengaruh anestesia epidural torasik pada perfusi splanknik, translokasi bakteri, dan perubahan histopatologi organ-organ splanknik pada renjatan perdarahan eksperimental pada beruk (Macaca nemestrina). Enam belas Macaca nemestrina ditentukan secara acak masuk ke dalam salah satu dari dua kelompok, yaitu kelompok lidokain (n = 8), yang mendapat anestesia umum ditambah anestesi epidural torasik lidokain; dan kelompok salin, yang mendapat anestesia umum saja (n =8) sebagai kontrol. Renjatan perdarahan dibuat dengan mengeluarkan darah hewan secara bertahap sampai tekanan darah arteri

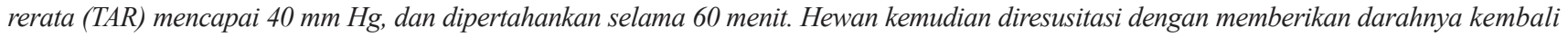
disertai cairan ringer laktat (RL). Setelah resusitasi, diberikan lidokain $2 \%$ epidural pada kelompok lidokain dan salin pada kelompok kontrol. Resusitasi yang dilakukan setelah satu jam renjatan perdarahan, dengan variabel hemodinamik dan luaran urin kembali normal, menunjukkan bahwa pada kelompok salin tidak ada perbaikan perfusi splanknik. PgCO2, P(g-a)CO2, dan pHi menetap pada nilai kritis dan cenderung memburuk pada kelompok salin. Berlawanan dengan kelompok salin, pada kelompok lidokain perfusi splanknik cenderung membaik. Keadaan ini didukung dengan dijumpainya translokasi bakteri yang lebih sedikit dan perubahan histopatologi organ splanknik yang lebih baik. Penelitian ini menyimpulkan bahwa anestesia epidural torasik lidokain memperkecil hipoperfusi splanknik pascaresusitasi renjatan perdarahan pada Macaca nemestrina. (Med J Indones 2008; 17: 73-81)
\end{abstract}

\begin{abstract}
The purpose of present study was to assess the effects of thoracic epidural anesthesia on splanchnic perfusion, bacterial translocation and histopathologic changes in experimental hemorrhagic shock in short-tailed macaques (Macaca nemestrina). Sixteen Macaca nemestrinas were randomly assigned to one of two groups i.e. the lidocaine group $(n=8)$, receiving general anesthesia plus lidocaine thoracic epidural anesthesia; and the saline group $(n=8)$, receiving general anesthesia alone as control. Hemorrhagic shock was induced by withdrawing blood gradually to a mean arterial pressure (MAP) of $40 \mathrm{~mm} \mathrm{Hg}$, and maintained for 60 minutes. Animals were then resuscitated with their own blood and ringer lactate solution (RL). After resuscitation, epidural lidocaine 2\% was given in the lidocaine group and saline in the control group. Resuscitation that was performed after one hour hemorrhagic shock, with hemodynamic variables and urine output returned to normal, revealed there was no improvement of splanchnic perfusion. PgCO2, P(g-a)CO2, and pHi remained in critical value and tended to deteriorate in the saline group. Contrast to saline group, splanchnic perfusion in lidocaine group tended to improve. This condition was supported by the finding of less bacterial translocation and better histopathologic changes in lidocaine thoracic epidural anesthesia group than in saline group. This study concludes that lidocaine thoracic epidural anesthesia attenuates splachnic hypoperfusion in post-resuscitation hemorrhagic shock in Macaca nemestrina. (Med J Indones 2008; 17: 73-81)
\end{abstract}

Keywords: thoracic epidural anesthesia, lidocaine, hemorrhagic shock, splanchnic hypoperfusion, bacterial translocation

The main objective of resuscitation in a hemorrhagic shock is to replace the blood loss and to stop the source of hemorrhage. Although resuscitation is done successfully and the patient returns to normal state, the hemodynamic variables often return to the pre-shock state, it is not rare that at the end the patient would die in Intensive Care Unit (ICU) due to multiple organ failure (MOF). Several authors mentioned that there

Department of Anesthesiology and Intensive Therapy, Faculty of Medicine, University of Indonesia/Dr. Cipto Mangunkusumo Hospital, Jakarta, Indonesia is a relationship between multiple organ failure and splanchnic hypo-perfusion. ${ }^{1,2}$

Splanchnic circulation plays a role as circulatory sink in acute hemorrhage to maintained brain and heart perfusion by way of sympathetic nervous system induced vasoconstriction. Prolonged reduction of splanchnic blood flow causes ischemia and hypoxia of splanchnic tissues. It also leads to increase the permeability of intestinal mucosa and facilitate bacterial translocation. The reperfusion of previously ischemic tissue also will activate the inflammation mediators' network. 
Experimental studies proved that hemorrhage with or without arterial hypotension will be followed by blood flow depression or arterial vasoconstriction which last for long period on mesenteric area despite sufficient resuscitation. Pain and tissue injury due to trauma also stimulate the sympathetic nervous system which worsen reduction of microcirculation in splanchnic area.

In anesthesiology, epidural anesthesia is one of methods that can be applied to reduce the sympathetic activity. Thoracic epidural anesthesia (TEA) can inhibit splanchnic sympathetic nervous system completely. The local anesthetic which is injected into the epidural space and absorbed by the blood vessels in that space is expected to have a systemic effect to prevent ischemia-reperfusion syndrome.

Shibata et $\mathrm{al}^{3}$ reported that high TEA in dogs improved the survival from experimental hemorrhagic shock. Adolphs et $\mathrm{al}^{4}$ in their experimental study in rats reported that TEA proved to improve intestinal microcirculation during hypotension due to acute hemorrhage. This also reduce leucocytes rolling - an early stage of inflammation reaction to low flow.

Based on the fact that inadequate splanchnic perfusion may cause multiple organ failure which increases the risk of death in critically ill patient and that the TEA effects are thought to improve splanchnic perfusion, this experimental study was done to evaluate the effects of TEA given after reperfusion on the splanchnic perfusion in hemorrhagic shock.

\section{METHODS}

This experimental study was conducted in IPB Veterinary Hospital, Bogor. The study protocol was approved by the Animal Care and Use Committee IPB, Bogor. Sixteen healthy adult Macaca nemestrinas were randomly assigned into two groups, i.e. lidocaine group $(\mathrm{n}=8)$ and saline group as control $(\mathrm{n}=8)$. After a 12 hour fasting for food (water ad libitum) prior to induction, both groups were anesthetized with ketamine during preparation, under which an epidural catheter was inserted at T7-8 and gastric tonometry catheter was inserted under fluoroscopy guidance. The position of the catheter was confirmed by fluoroscopy using $2 \mathrm{ml}$ of iopamidol contrast medium. The animals were then mechanically ventilated under general anesthesia (endotracheal intubation facilitated with succiniylcholine, $\mathrm{N}_{2} \mathrm{O}-\mathrm{O}_{2}: 50 \%-50 \%$, halothane $0.5 \%$ and rocuronium) using Amsterdam Infant Ventilator, maintained normocapnia $\left(\mathrm{PaCO}_{2} \pm 40 \mathrm{~mm} \mathrm{Hg}\right)$. Central venous catheter was inserted through femoral vein for central venous pressure (CVP) monitoring and administration of maintenance fluid. Ringer Dextrose $5 \%(\mathrm{RD})$ was used as fluid and calories replacement during fasting, and Ringer Lactate (RL) as maintenance fluid. Arterial catheters were placed in both femoral arteries for hemodynamic monitoring and blood withdrawal. Hemorrhagic shock was induced by withdrawing blood gradually to a mean arterial pressure (MAP) of $40 \mathrm{~mm} \mathrm{Hg}$, and maintained for 60 minutes. Animals were then resuscitated with their own blood and crystalloid solution (RL). Post resuscitation, in the treated group epidural lidocaine $2 \%$ was given and the control group received saline. During this study $\mathrm{PgCO}_{2}$, $\mathrm{P}(\mathrm{g}-\mathrm{a}) \mathrm{CO}_{2}, \mathrm{pHi}$, hemodynamic parameters, acid-base balance and lactate were monitored. Specimens for blood culture were taken before shock and at the end of study. Biopsies of the intestinal, liver, and kidney were done. Hemodynamic parameters were monitored using PiCCO semi-invasive transpulmonary thermodilution technique. Blood gas analysis, acid base and blood lactate level were measured by I-Stat Analyzer. Splanchnic perfusion was measured by gastric tonometry Datex Ohmeda/ GE, which measured $\mathrm{PgCO} 2, \mathrm{P}(\mathrm{g}-\mathrm{a}) \mathrm{CO} 2$ and pHi continuously. Histopathology's studies were done by Pathology and Lipid Lab, PSSP LPPM-IPB, Bogor, and blood cultures by Prodia Lab, Bogor.

The statistical analysis was done with Student T-test and General Linear Model Repeated Measures and One-Way Anova. Mann Whitney was used if the analysis can not be done with the previous methods. $\mathrm{P}<0.005$ was considered statistically significant and the values were expressed with standard deviation. The software used was SPSS 13.0 and for the Mann Whitney test was Minitab 11 for Windows.

\section{RESULTS}

No significant differences were noted between two groups with respect to body weight, body length, age, and bleeding volume (Table 1). Radiographic findings indicated that contrast medium was spreading from approximately $\mathrm{T} 1$ to $\mathrm{T} 11$ in saline group and from C6 to T11 in lidocaine group. 


\section{Hemodynamic Variables in Pre-Hemorrhagic Shock}

No significant differences were evident in baseline pre-hemorrhagic shock hemodynamic variables between the two groups, except cardiac index (CI) (Table 1). Although CI pre-hemorrhagic shock in lidocaine group significantly less than control group, the splanchnic perfusion pre-hemorrhagic shock between the two groups were similar based on gastric tonometry. $\mathrm{PgCO}_{2}$, $\mathrm{P}(\mathrm{g}-\mathrm{a}) \mathrm{CO}_{2}$, and $\mathrm{pHi}$ in pre-hemorrhagic shock did not differ significantly between the two groups and were within the normal range (Table 2).

Table 1. Characteristics of Macaca nemestrina and Hemodynamic Variables in Pre-Hemorrhagic Shock

\begin{tabular}{|c|c|c|c|c|c|}
\hline & Group & $\mathbf{n}$ & Mean & $\begin{array}{c}\text { Standard } \\
\text { Deviation } \\
\text { (SD) }\end{array}$ & $\mathbf{p}$ \\
\hline \multirow{2}{*}{ Body Weight (kg) } & Saline & 8 & 12.74 & 2.77 & \multirow{2}{*}{$>0.05$} \\
\hline & Lidocaine & 8 & 12.14 & 2.99 & \\
\hline \multirow{2}{*}{ Body Length (cm) } & Saline & 8 & 95.69 & 5.68 & \multirow{2}{*}{$>0.05$} \\
\hline & Lidocaine & 8 & 93.37 & 6.76 & \\
\hline \multirow{2}{*}{ Age (yrs) } & Saline & 8 & 13.87 & 3.23 & \multirow{2}{*}{$>0.05$} \\
\hline & Lidocaine & 8 & 16.50 & 3.82 & \\
\hline \multirow{2}{*}{ Bleeding Volume (mL) } & Saline & 8 & 207.37 & 89.45 & \multirow{2}{*}{$>0.05$} \\
\hline & Lidocaine & 8 & 230.25 & 69.79 & \\
\hline \multirow{2}{*}{ MAP (mm Hg) } & Saline & 8 & 95.75 & 13.45 & \multirow{2}{*}{$>0.05$} \\
\hline & Lidocaine & 8 & 96.25 & 13.71 & \\
\hline \multirow{2}{*}{ HR (beats/min) } & Saline & 8 & 121.88 & 32.31 & \multirow{2}{*}{$>0.05$} \\
\hline & Lidocaine & 8 & 105.88 & 22.14 & \\
\hline \multirow{2}{*}{$\mathrm{CVP}(\mathrm{mm} \mathrm{Hg})$} & Saline & 8 & 5.38 & 2.77 & \multirow{2}{*}{$>0.05$} \\
\hline & Lidocaine & 8 & 7.13 & 2.75 & \\
\hline \multirow{2}{*}{$\mathrm{CI}\left(\mathrm{L} / \mathrm{min} / \mathrm{m}^{2}\right)$} & Saline & 8 & 3.32 & 0.52 & \multirow{2}{*}{$<0.05$} \\
\hline & Lidocaine & 8 & 2.72 & 0.41 & \\
\hline
\end{tabular}

MAP: mean arterial pressure, HR:heart rate, CVP:central venous pressure, $\mathrm{CI}$ :cardiac index

Table 2. $\mathrm{PgCO}_{2}, \mathrm{P}(\mathrm{g}-\mathrm{a}) \mathrm{CO}_{2}$, pHi, Blood Acid Base Balance and Lactate in Pre-Hemorrhagic Shock

\begin{tabular}{|c|c|c|c|c|c|}
\hline & Group & $\mathbf{n}$ & Mean & $\begin{array}{c}\text { Standard } \\
\text { Deviation } \\
\text { (SD) }\end{array}$ & $\mathbf{p}$ \\
\hline \multirow{2}{*}{$\mathrm{PgCO}_{2}(\mathrm{kPa})$} & Saline & 8 & 6.35 & 1.62 & \multirow{2}{*}{$>0.05$} \\
\hline & Lidocaine & 8 & 6.69 & 2.36 & \\
\hline \multirow{2}{*}{$\mathrm{P}(\mathrm{g}-\mathrm{a}) \mathrm{CO}_{2}(\mathrm{kPa})$} & Saline & 8 & 0.47 & 2.07 & \multirow{2}{*}{$>0.05$} \\
\hline & Lidocaine & 8 & 1.14 & 1.83 & \\
\hline \multirow{2}{*}{ pHi (unit) } & Saline & 8 & 7.38 & 0.13 & \multirow{2}{*}{$>0.05$} \\
\hline & Lidocaine & 8 & 7.34 & 0.10 & \\
\hline \multirow{2}{*}{$\mathrm{pHa}$ (unit) } & Saline & 8 & 7.39 & 0.09 & \multirow{2}{*}{$>0.05$} \\
\hline & Lidocaine & 8 & 7.41 & 0.06 & \\
\hline \multirow{2}{*}{$\mathrm{PaCO}_{2}(\mathrm{mmHg})$} & Saline & 8 & 44.21 & 10.60 & \multirow{2}{*}{$>0.05$} \\
\hline & Lidocaine & 8 & 41.74 & 5.06 & \\
\hline \multirow{2}{*}{$\mathrm{BE}(\mathrm{mmol} / \mathrm{L})$} & Saline & 8 & 0.75 & 2.96 & \multirow{2}{*}{$>0.05$} \\
\hline & Lidocaine & 8 & 1.37 & 2.33 & \\
\hline \multirow{2}{*}{ Lactate $(\mathrm{mmol} / \mathrm{L})$} & Saline & 8 & 1.44 & 0.91 & \multirow{2}{*}{$>0.05$} \\
\hline & Lidocaine & 8 & 1.94 & 1.21 & \\
\hline
\end{tabular}

$\mathrm{PgCO}_{2}$ : partial pressure of gastric $\mathrm{CO}_{2}, \mathrm{P}(\mathrm{g}-\mathrm{a}) \mathrm{CO}_{2}$ : partial pressure difference of gastric and arterial $\mathrm{CO}_{2}$, $\mathrm{pHi}$ : gastric intramucosa $\mathrm{pH}$ 
Acid Base Balance and Blood Lactate in Pre-Hemorrhagic Shock

No significantly difference of $\mathrm{pHa}$ (arterial $\mathrm{pH}$ ), $\mathrm{PaCO} 2$ (partial pressure of arterial $\mathrm{CO} 2$ ), and $\mathrm{BE}$ (base excess) between the two groups in pre-hemorrhagic shock and they were within the normal limit (Table 2).

\section{Fluid Infusion}

Beside their own blood, animals also received crystalloid infusion (Ringer Lactate solution) for resuscitation and, Ringer Dextrose 5\% solution for fluid and calories requirement during fasting. Total amount of fluid infusion in both group were not significantly difference during experimental study (Table 3 ).

\section{Hemodynamic variables, acid base balance and blood lactate after resuscitation and after epidural anesthesia}

At $90^{\text {th }}$ minute after resuscitation with blood and crystalloid, hemodynamic variables returned to the normal limit pre-shock condition, blood acid base and lactate were not significantly difference between the two groups before administration of TEA (Table 4).

Table 3. Fluid Infusion during Experimental Study

\begin{tabular}{lllccc}
\hline & Group & $\mathbf{n}$ & Mean & $\begin{array}{c}\text { Standard Deviation } \\
\text { (SD) }\end{array}$ & p \\
\hline $\begin{array}{l}\text { Total of Infusion } \\
(\mathrm{mL})\end{array}$ & Saline & 8 & 3062.50 & 1015.50 & $>0.05$ \\
Ringer Lactate & Lidocaine & 8 & 3562.50 & 821.04 & $>0.05$ \\
$(\mathrm{~mL})$ & Saline & 8 & 2375.00 & 1060.66 & 1224.74 \\
Ringer Dextrose 5\% & Lidocaine & 8 & 3000.00 & 458.06 & $>0.05$ \\
$(\mathrm{~mL})$ & Saline & 8 & 687.50 & 623.21 & \\
\hline
\end{tabular}

Table 4. Hemodynamic Variables, Blood Acid Base and Lactate after resuscitation

\begin{tabular}{|c|c|c|c|c|c|}
\hline & Group & $\mathbf{n}$ & Mean & $\begin{array}{c}\text { Standard } \\
\text { Deviation } \\
\text { (SD) }\end{array}$ & $\mathbf{p}$ \\
\hline \multirow{2}{*}{ MAP (mmHg) } & Saline & 8 & 77.25 & 19.83 & \multirow{2}{*}{$>0.05$} \\
\hline & Lidocaine & 8 & 86.88 & 21.78 & \\
\hline \multirow{2}{*}{ HR (beats/min) } & Saline & 8 & 136.13 & 18.16 & \multirow{2}{*}{$>0.05$} \\
\hline & Lidocaine & 8 & 129.25 & 14.77 & \\
\hline \multirow{2}{*}{ CVP (mmHg) } & Saline & 8 & 6.75 & 5.17 & \multirow{2}{*}{$>0.05$} \\
\hline & Lidocaine & 8 & 9.00 & 3.25 & \\
\hline \multirow{2}{*}{$\mathrm{CI}\left(\mathrm{L} / \mathrm{min} / \mathrm{m}^{2}\right)$} & Saline & 8 & 2.78 & 1.11 & \multirow{2}{*}{$>0.05$} \\
\hline & Lidocaine & 8 & 2.27 & 0.98 & \\
\hline \multirow{2}{*}{ pHa (unit) } & Saline & 8 & 7.27 & 0.16 & \multirow{2}{*}{$>0.05$} \\
\hline & Lidocaine & 8 & 7.27 & 0.08 & \\
\hline \multirow{2}{*}{$\mathrm{PaCO}_{2}(\mathrm{mmHg})$} & Saline & 8 & 49.33 & 13.43 & \multirow{2}{*}{$>0.05$} \\
\hline & Lidocaine & 8 & 41.13 & 3.58 & \\
\hline \multirow{2}{*}{$\mathrm{BE}(\mathrm{mmol} / \mathrm{L})$} & Saline & 8 & -7.62 & 5.83 & \multirow{2}{*}{$>0.05$} \\
\hline & Lidocaine & 8 & -7.75 & 3.58 & \\
\hline \multirow{2}{*}{ Lactate $(\mathrm{mmol} / \mathrm{L})$} & Saline & 8 & 5.26 & 2.52 & \multirow{2}{*}{$>0.05$} \\
\hline & Lidocaine & 8 & 4.99 & 1.81 & \\
\hline
\end{tabular}


Table 5. Hemodynamic Variables, Blood Acid Base and Lactate at $270^{\text {th }}$ minute

\begin{tabular}{|c|c|c|c|c|c|}
\hline & Group & $\mathbf{n}$ & Mean & $\begin{array}{c}\text { Standard } \\
\text { Deviation } \\
\text { (SD) } \\
\end{array}$ & $\mathbf{p}$ \\
\hline \multirow{2}{*}{ MAP (mmHg) } & Saline & 7 & 54.43 & 28.577 & \multirow{2}{*}{$>0.05$} \\
\hline & Lidocaine & 8 & 73.75 & 32.221 & \\
\hline \multirow{2}{*}{ HR (beats/min) } & Saline & 7 & 133.86 & 40.043 & \multirow{2}{*}{$>0.05$} \\
\hline & Lidocaine & 8 & 112.63 & 30.859 & \\
\hline \multirow{2}{*}{ CVP $(\mathrm{mmHg})$} & Saline & 7 & 8.29 & 5.707 & \multirow{2}{*}{$>0.05$} \\
\hline & Lidocaine & 8 & 9.00 & 3.295 & \\
\hline \multirow{2}{*}{$\mathrm{CI}\left(\mathrm{L} / \mathrm{min} / \mathrm{m}^{2}\right)$} & Saline & 6 & 2.1483 & 1.02539 & \multirow{2}{*}{$>0.05$} \\
\hline & Lidocaine & 7 & 1.9314 & 0.92353 & \\
\hline \multirow{2}{*}{ pHa (unit) } & Saline & 7 & 7.3086 & 0.05984 & \multirow{2}{*}{$>0.05$} \\
\hline & Lidocaine & 8 & 7.2860 & 0.14725 & \\
\hline \multirow{2}{*}{$\mathrm{PaCO}_{2}(\mathrm{mmHg})$} & Saline & 7 & 40.2857 & 6.64691 & \multirow{2}{*}{$>0.05$} \\
\hline & Lidocaine & 8 & 41.9625 & 9.25680 & \\
\hline \multirow{2}{*}{$\mathrm{BE}(\mathrm{mmol} / \mathrm{L})$} & Saline & 7 & -4.7143 & 4.92322 & \multirow{2}{*}{$>0.05$} \\
\hline & Lidocaine & 8 & -7.0000 & 5.73212 & \\
\hline \multirow{2}{*}{ Lactate $(\mathrm{mmol} / \mathrm{L})$} & Saline & 7 & 4.2557 & 2.22966 & \multirow{2}{*}{$>0.05$} \\
\hline & Lidocaine & 8 & 4.8863 & 3.14749 & \\
\hline
\end{tabular}

After resuscitation and epidural anesthesia administration (at the end of study - at $270^{\text {th }}$ minute) hemodynamic variables, blood acid base and lactate in both groups were not significantly difference (Table 5).

\section{PgCO2, $\mathrm{P}(\mathrm{g}-\mathrm{a}) \mathrm{CO}$, and $\mathrm{pHi}$ changing during experimental study}

\section{$\mathrm{PgCO} 2$ changing}

At $30^{\text {th }}$ and $60^{\text {th }}$ minute of hemorrhagic shock, $\mathrm{PgCO} 2$ in both groups increased according to shock duration (Figure 1a). After resuscitation, at $90^{\text {th }}$ minute and subsequently, $\mathrm{PgCO} 2$ in saline group tended to increase until the end of experiment $\left(270^{\text {th }}\right.$ minute). While $\mathrm{PgCO} 2$ in lidocaine group after resuscitation tended not to increase and even decreased. At $90^{\text {th }}$ minute, $\mathrm{PgCO} 2$ in saline group was: $19.07 \pm 8.02 \mathrm{kPa}$ and $\mathrm{PgCO} 2$ of lidocaine group was: $11.03 \pm 7.96 \mathrm{kPa}$. At $150^{\text {th }}$ minute, the values were $19.54 \pm 8.59$ versus $9.94 \pm 8.36 \mathrm{kPa}$; And at $270^{\text {th }}$ minute, the values were $20.71 \pm 9.75 \mathrm{kPa}$ and $\mathrm{PgCO} 2$ lidocaine: $10.11 \pm 8.34 \mathrm{kPa} \cdot \mathrm{PgCO} 2$ between group were significantly difference since the minutes of $90^{\text {th }}, 150^{\text {th }}$ till $270^{\text {th }}$ (one-way Anova $\mathrm{p}=0.038 ; 0.023$ and 0.041 ; respectively). This suggest that splanchnic perfusion lidocaine group better than saline group.
$\mathrm{P}(\mathrm{g}-\mathrm{a}) \mathrm{CO} 2$ changing:

$\mathrm{P}(\mathrm{g}-\mathrm{a}) \mathrm{CO} 2$ of both group start from pre-hemorrhagic shock, at $30^{\text {th }}$ minute and $60^{\text {th }}$ minute shock appeared to increase according to shock duration (Figure 1b). After resuscitation, minutes $90^{\text {th }}$ and so forth $\mathrm{P}(\mathrm{g}-\mathrm{a}) \mathrm{CO} 2$ in saline group continued to increase until the end of experiment $(12.32 \pm 8.98 \mathrm{~mm} \mathrm{Hg}, 13.33 \pm 9.70 \mathrm{~mm}$ $\mathrm{Hg}$, and $15.36 \pm 9.55 \mathrm{~mm} \mathrm{Hg}$, respectively). Contrast to saline group, the $\mathrm{P}(\mathrm{g}-\mathrm{a}) \mathrm{CO} 2$ in lidocaine group tended to decrease since minute $90^{\text {th }}(5.38 \pm 8.13 \mathrm{~mm} \mathrm{Hg}, 4.63$ $\pm 7.44 \mathrm{~mm} \mathrm{Hg}$, and $4.53 \pm 7.38 \mathrm{~mm} \mathrm{Hg}$, respectively). $\mathrm{P}(\mathrm{g}-\mathrm{a}) \mathrm{CO} 2$ between groups were significantly difference since the minutes of $150^{\text {th }}$ till $270^{\text {th }}$ (one-way Anova $\mathrm{p}=$ 0.035 and 0.028 , respectively)

The increasing $\mathrm{P}(\mathrm{g}-\mathrm{a}) \mathrm{CO} 2$ in saline group suggest deterioration of splanchnic perfusion, while decreasing $\mathrm{P}(\mathrm{g}-\mathrm{a}) \mathrm{CO} 2$ in lidocaine group indicated a changing toward improvement of splanchnic perfusion.

\section{pH Gastric Intramucosa changing:}

Figure 1c shows $\mathrm{pH}$ gastric intramucosa $(\mathrm{pHi})$ changing during experimental study. $\mathrm{pHi}$ in both groups during hemorrhagic shock, at $30^{\text {th }}$ minute in saline group was $7.10 \pm 0.22$ and in lidocaine group was $7.12 \pm 0.21$; at $60^{\text {th }}$ minute in saline group was 7.000 .19 and in lidocaine group was $7.07 \pm 0.21$. After resuscitation, from $90^{\text {th }}, 150^{\text {th }}$ minute to the end of experiment at $270^{\text {th }}$ minute, $\mathrm{pHi}$ in saline group appeared always lower than lidocaine group. 

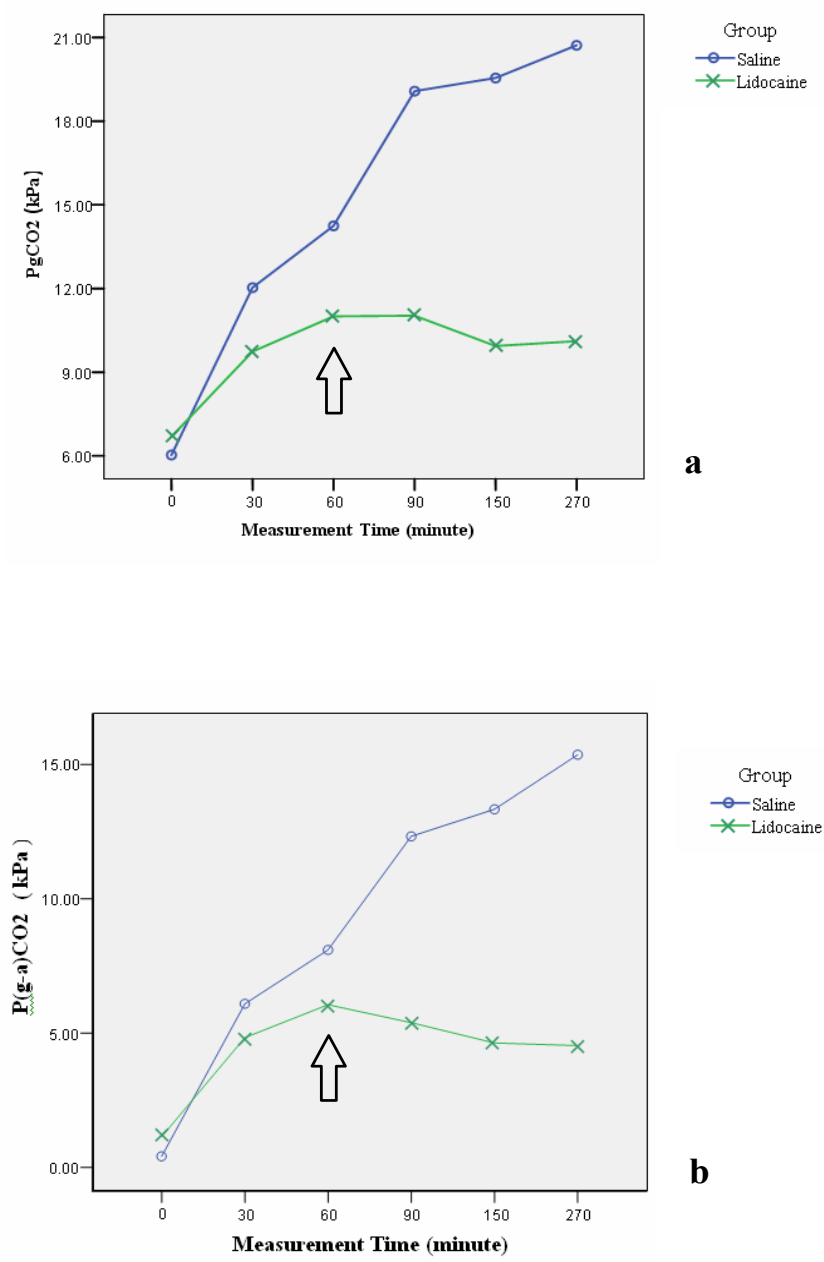

b
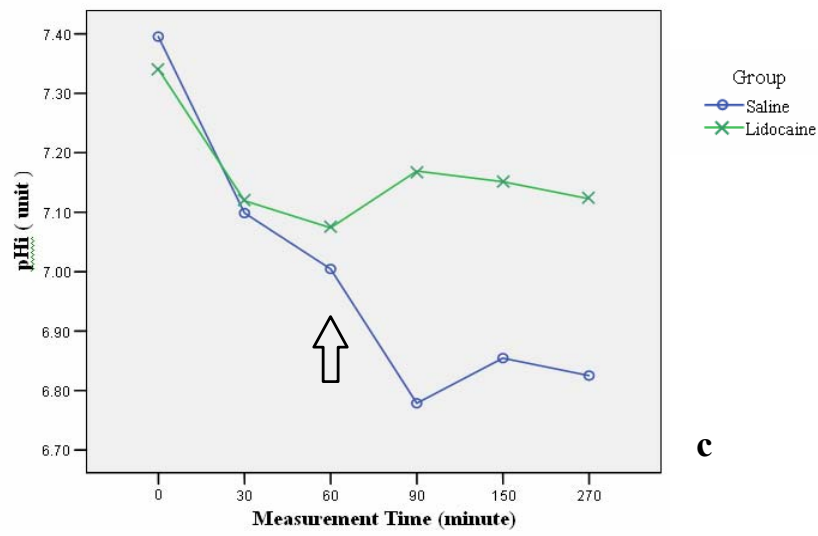

Figure la, $b, c . \mathrm{PgCO}_{2}, \mathrm{P}(\mathrm{g}-\mathrm{a}) \mathrm{CO}_{2}$, and Gastric intramucosa $\mathrm{pH}$ (pHi) changing during experimental study $0^{\text {th }}$ to $60^{\text {th }}$ minute: hemorrhagic shock

Arrow : epidural anesthesia starts 


\section{Bacterial translocation}

The results of blood culture taken at the end of study $\left(270^{\text {th }}\right.$ minute $)$, were difference from those taken before shock (0 minute), as follows

1. Saline group :

- Lactococcus garvieae, found in one animal

- Streptococcus viridans, found in two animals

- Serratia mercescens, found in one animal

- Escherichia coli, found in two animals

- Pseudomonas aeruginosa, found in one animal

There were 7 bacterial translocations in 8 animals $(87.5 \%)$

2. Lidocaine group :

- Serratia marcescens, found in three animals

- Streptococcus viridans, found in one animal

There were 4 bacterial translocations in 8 animals $(50 \%)$

Bacterial translocations which originate from gastrointestinal tract in saline group occurred more frequently than in lidocaine group ( $87.5 \%$ vs $50 \%)$.

\section{Histopathology changing}

Histopathology examination results were arranged according to the degree of cell changing and necrosis cell per a microscope view.

Degree 1: no change

Degree 2: mild changing, which cell damage less than $25 \%$

Degree 3: moderate changing, with cell damage $25-50 \%$

Degree 4: moderate to severe changing, which means cell damage $50-75 \%$

Degree 5: severe changing, which means cell damage about $75-100 \%$
Histopathology results of duodenum in lidocaine group were better than saline group $(p=0.0456)$. Other intraabdominal organs, even not significantly difference, appeared better in lidocaine group than saline group (except ileum) (Table 6).

\section{DISCUSSION}

Normal value of $\mathrm{PgCO} 2$ is $<6.5 \mathrm{kPa}, \mathrm{P}(\mathrm{g}-\mathrm{a}) \mathrm{CO} 2$ is $1 \mathrm{kPa}$, and $\mathrm{pHi}$ is $>7.35$. $\mathrm{PgCO} 2$ is thought critical if $>8.65 \mathrm{kPa}$; and $\mathrm{P}(\mathrm{g}-\mathrm{a}) \mathrm{CO} 2$ is critical if $>3.33-4.66$ $\mathrm{kPa} .(1 \mathrm{kPa}=7.52 \mathrm{~mm} \mathrm{Hg})$. Gastrointestinal mucosa hypoperfusion is present if $\mathrm{pHi}$ less than 7,$32 ; \mathrm{PgCO}_{2}$ and $\mathrm{P}(\mathrm{g}-\mathrm{a}) \mathrm{CO}_{2}$ higher than critical value. ${ }^{5}$

So, splanchnic hypoperfusion condition as predicted in this hemorrhagic model can be obtained, which detected by any changing of $\mathrm{PgCO} 2, \mathrm{P}(\mathrm{g}-\mathrm{a}) \mathrm{CO} 2$, and $\mathrm{pHi}$ that after resuscitation, were in the range of critical splanchnic perfusion value.

Splanchnic hypoperfusion which occurred during hemorrhagic shock in this study was consistent with other previous studies with different model..$^{6-9}$ Resuscitation that was performed after one hour hemorrhagic shock with crystalloid and blood transfusion, and hemodynamic variables and urine output returned to normal, revealed there was no improvement of splanchnic perfusion detected by $\mathrm{PgCO} 2, \mathrm{P}(\mathrm{g}-\mathrm{a}) \mathrm{CO} 2$, and $\mathrm{pHi}$ that remained in critical value and tended to deteriorate in the saline group. This matter agrees with Scannel et al study ${ }^{9}$ reported that blood flow to splanchnic organs remained depressed after resuscitation even though blood flow to brain and kidney increased. Also, Edouard et $\mathrm{al}^{6}$ reported that a sustained splanchnic vasoconstriction remained occurred even though the adequate management have been done with attention to blood pressure and cardiac output.

Table 6. Degree of Histopathology changing

\begin{tabular}{|c|c|c|c|c|c|}
\hline Organ & Group & $\mathrm{n}$ & Median & $\mathrm{p}^{*}$ & CI 95\% \\
\hline \multirow[t]{2}{*}{ Liver } & Saline & 8 & 4 & 0.1973 & $-0.000-1.000$ \\
\hline & Lidocaine & 8 & 3 & & \\
\hline \multirow[t]{2}{*}{ Kidney } & Saline & 7 & 4 & 0.0946 & $-1.001-3.000$ \\
\hline & Lidocaine & 5 & 3 & & \\
\hline \multirow[t]{2}{*}{ Duodenum } & Saline & 8 & 3.5 & 0.0456 & $0.000-1.999$ \\
\hline & Lidocaine & 8 & 3 & & \\
\hline \multirow[t]{2}{*}{ Jejunum } & Saline & 8 & 4 & 0.4278 & $0.000-1.000$ \\
\hline & Lidocaine & 8 & 3.5 & & \\
\hline \multirow[t]{2}{*}{ Ileum } & Saline & 8 & 3 & 0.5557 & $-1.000-1.000$ \\
\hline & Lidocaine & 8 & 4 & & \\
\hline \multirow[t]{2}{*}{ Colon } & Saline & 8 & 3 & 0.3151 & $-0.999-2.000$ \\
\hline & Lidocaine & 8 & 3 & & \\
\hline
\end{tabular}

* Mann Whitney Test 
After resuscitation at $90^{\text {th }}$ minute and subsequently, splanchnic perfusion in saline group revealed progressively deteriorated, while in lidocaine group, it tended to improve. This study result was consistent to other previous studies. Adolphs et al. ${ }^{4}$ which used rat as hemorrhagic model reported that thoracic epidural anesthesia preserved gut from decreased microvascular perfusion and from increased leukocytes-endothelium interaction which related to hemorrhage/retransfusion. In another study, Sielenkamper et al. ${ }^{10}$ using intravital microscope to measure rat ileum mucosa blood flow during TEA (catheter tip at T7-9), reported that TEA increased mucosa blood flow and reduced irregular flow patterns such as stop-and-go flow in the capillary networks of the gut mucosa.

Contrast to the previous experimental study reports in animals or clinical studies, in which hemorrhagic shock was induced after epidural anesthesia. In this study thoracic epidural anesthesia was performed after hemorrhagic shock had occurred that was after resuscitation. Thoracic epidural anesthesia (TEA) was reported by several investigators could improve splanchnic perfusion ${ }^{10-12}$. Sielenkamper et al. ${ }^{10}$ reported that TEA increased gut mucosa blood flow and reduced intermittent flow in villous microcirculation in an experimental rat perfusion pressure. Kapral et al. ${ }^{11}$ reported that thoracic epidural anesthesia in patients who underwent major abdominal surgery was associated with better splanchnic perfusion. Jomura et al. ${ }^{12}$ also reported that epidural anesthesia reduced mortality rate of emergency abdominal surgery patients compared to general anesthesia. Those studies suggest that TEA may prevent splanchnic hypoperfusion. While in this study, where TEA was administered at post-hemorrhagic shock resuscitation, the similar result was found, i.e. the splanchnic perfusion was improved.

Difference to above studies, Meissner et al. ${ }^{13}$ using microsphere technique in dogs, reported that high thoracic epidural (T1-5) did not alter blood flow to splanchnic organ. The non alteration of blood flow to splanchnic area in this study can be explained by the fact that splanchnic sympathetic nerves (T5-T12) was not affected by this high epidural block.

Two other studies reported the effects of epidural anesthesia on gastric intramucosa $\mathrm{pH}$ during aortic reconstruction surgery. ${ }^{14,15}$ These both studies did not find any beneficial effect of epidural anesthesia on gastric intramucosa $\mathrm{pH}$. However, the $\mathrm{pH}$ measurement was performed in stomach while epidural catheter tip placed at L3-4 and T9-10, respectively. Thus, in both studies it appeared that epidural block did not include upper part of splanchnic organ during the measurement of intervention effect. ${ }^{14,15}$ At difference to two above studies, in this study, the catheter was inserted at T7-8 intervertebral space and the contrast medium was observed spreading from C6 to T11. So that lidocaine from TEA can be confirmed to include splanchnic sympathetic innervations (T5-11) which covered stomach in which tonometry measurement was placed.

In addition to inhibit nerve transmission, lidocaine has a significant anti-inflammatory property, ${ }^{16}$ and has a strong inhibitory effect on cytokine response to endotoxemia. ${ }^{17} \mathrm{Ai}$ et al. ${ }^{18}$ reported that TEA (tip of catheter at T8-T10) slowed progression of intestinal ischemia during hypoxia and give protection to an increasing portal endotoxin concentration.

There is developing evidence showing that lidocaine has direct effect on G protein-coupled receptors, such as lysophosphatidic acid (LPA) receptor ${ }^{19}$, which involve in platelet activation, inflammation and wound healing, as also thromboxane receptor ${ }^{20}$, which involve in platelet aggregation and release of NE contain granules.

Blood culture results taken at the beginning and at the end of the study revealed that in saline group more positive bacterial culture was found which originated from gastrointestinal tract organisms, compared to lidocaine epidural group. These findings indicated that bacterial translocation opportunity is higher in saline group than lidocaine group. This condition is in agreement with histopathology results which showed that gut condition (except ileum) of saline group was worse than lidocaine group.

These study results, revealed that TEA can preserve splanchnic perfusion better than saline after resuscitation in hemorrhagic shock. This is supported by histopathology and blood culture results. Histopathology results proved gut (except ileum), liver and kidney in lidocaine epidural group appeared better than saline group.

It is concluded that thoracic epidural anesthesia with lidocaine gives better protection on splanchnic perfusion after experimental hemorrhagic shock in Macaca nemestrina as witnessed by less bacterial 
translocation and better histopathologic appearance compared to saline.

\section{Acknowledgements}

I would like to express my great thanks to all staff members of Veterinary Hospital and Primate Centre Institute of Agriculture Bogor, who help this experimental study done, especially to Erni Sulistiawati, Dr, drh; Irma, Dr; Diah, drh; Huda, drh; Vivi, drh; and Dra Lies. Special thanks also to Prof. Agus Firmansyah,dr,Dr,SpA(K); Prof. Rusli Thaib, dr, SpAnKIC; Prof. Dondin Sajuthi, drh, PhD; Prof. Aryono Djuned Pusponegoro, dr, SpBD, Dr; Prof. Sri Bekti Subakir, dr,MS, Dr.; Prof. Siti Chasnak Saleh, dr, SpAnKIC; Adang Bachtiar, dr, MPH, DSc; Gunanti, drh, MSc, Dr; Prof. Sarwono Waspadji, dr, Dr, SpPD-KEMD and Prof Siti Aisah Boediardja, dr, Dr, SpK.K.(K); who have reviewed this study. Thanks also to Nafrialdy, dr, PhD, SpFK, who has corrected this manuscript.

\section{REFERENCES}

1. Ackland G, Grocott M, Mythen M. Understanding gastrointestinal perfusion in critical care: so near, and yet so far. Crit Care. 2000;4:269-81.

2. Schwarte L, Stevens M, Ince C. Splanknik perfusion and oxygenation in critical illness. In: Vincent J-L, editor. Yearbook of intensive care and emergency medicine: Springer; 2006. p. 627-40.

3. Shibata K, Y Y, S M. Effects of Epidural Anesthesia on Cardiovascular Response and Survival in Experimental Hemorrhagic Shock in Dogs. Anesthesiology. 1989;71: 953-9.

4. Adolphs J, Schmidt D, Mousa S, Kamin B, Korsukewitz I, Habazettl H, et al. Thoracic epidural anesthesia attenuates hemorrhage-induced impairment of intestinal perfusion in rats. Anesthesiology. 2003;99:685-92.

5. Heard S. Gastric tonometry. The hemodynamic monitor of choice (pro). Chest. 2003;123:469S - 74S.

6. Edouard A, Degremont A-C, Duranteau J, Pussard E, Berdeaux A, Samii K. Heterogenous regional vascular responses to simulated transient hypovolemia in man. Intensive Care Med. 1994;20:414-20.

7. Scalia S, Burton H, Van Wylen D, Steinberg S, Hoffman $\mathrm{A}$, Roche F, et al. Persistent arteriolar constriction in microcirculation of the terminal ileum following moderate hemorrhage hypovolemia and volume restoration. J Trauma. 1990;30:713-8.

8. Vatner S. Effects of hemorrhage on regional blood flow distribution in $\operatorname{dogs}$ and primates. J Clin Invest. 1974;54:225-35.

9. Scannell G, Clark L, Waxman K. Regional flow during experimental hemorrhage and crystalloid resuscitation: persistence of low flow to the splanchnic organs. Resuscitation. 1992;23:217-25.

10. Sielenkamper A, Eiker K, Van Aken H. Thoracic epidural anesthesia increases mucosal perfusion in ileum of rats. Anesthesiology. 2000;93:844-51.

11. Kapral S, Gollmann G, Bachmann D, Prohaska B, Likar R, Jandrasits $\mathrm{O}$, et al. The effects of thoracic epidural anesthesia on intraoperative visceral perfusion and metabolism. Anesth Analg. 1999;88:402-6.

12. Jomura K, Hamada T, Sugiki K, Ito Y. Epidural anesthesia reduces mortality rate in the patients after abdominal surgery. Matsui. 1997;46:1602-8.

13. Meissner A, Weber T, Van Aken H, Rolf N. Limited upper thoracic epidural block and splanchnic perfusion in dogs. Anesth Analg. 1999;89:1378-81.

14. Väisänen $\mathrm{O}$, Parviainen I, Ruokonen E, Hippelainen M, Berg E, Takala J. Epidural analgesia with bupivacaine does not improve splanchnic tissue perfusion after aortic reconstruction surgery. Br J Anesth. 1998;81:893-8.

15. Piper S, Boldt J, Schmidt C, Maleck W, Brosch C, Kumle B. Hemodynamics, intra-mucosal $\mathrm{pH}$ and regulators of circulation during perioperative epidural analgesia. Can J Anesth. 2000;47:631-7.

16. Hollmann M, Durieux M. Local anesthetics and the inflammatory response: a new therapeutic indication? Anesthesiology. 2000;93:858-75.

17. Taniguchi T, Shibata K, Yamamoto K, et a. Effects of lidocaine administration on hemodynamics and cytokine responses to endotoxaemia in rabbits. Crit Care Med. 2000;28:755-9.

18. Ai K, Kotake Y, Satoh T, Serita R, Takeda J, Morisaki H. Epidural anesthesia retards intestinal acidosis portal vein endotoxin in concentrations during progressive hypoxia in rabbits. Anesthesiology. 2001;96:263-9.

19. Nietgen G, Chan C, Durieux M. Inhibition of lysophosphatidate signaling by lidocaine and bupivacaine. Anesthesiology. 1997;86:1112-9.

20. Hollmann M, McIntire W, Garrison J, Durieux M. Inhibition of mammalian $\mathrm{Gq}$ protein function by local anesthetics. Anesthesiology. 2002;97:1451-7. 